\title{
Imperatives of Career Management and its Effect on Employee Performance
}

John Nkeobuna Nnah Ugoani

\begin{abstract}
Department of Management Sciences, College
of Management and Social Sciences, Rhema University, Nigeria.

Email:drjohnugraani@yahoo.com Tel:08036066338
\end{abstract}

Licensed:

This work is licensed under a Creative Commons Attribution 4.0 License.

Keywords:

Corporate education

Entrepreneurship education

Knowledge-driven

Learning

Management control.

JEL Classification:

M1O; M12.

Accepted: 25 October 2019

Published: 11 November 2019

\begin{abstract}
Career management through corporate education is imperative to the survival of any organization due to the rapid changes in the global economy where business is knowledge-driven. Corporate education emphasizes management strategies and mechanisms for management control, co-ordination, communication, monitoring, learning and adjustment. It is expected that for these processes to be effective, organizational structures must become less hierarchical and more open to information and employee involvement at all levels to enhance adaptive strategies that require very flexible management processes. Eighty respondents participated in the study conducted through the exploratory research design using secondary and primary data. Result of the analysis of data showed strong positive correlation between career management and employee performance. The study was not however exhaustive due to some limitations. Therefore, further study could examine the relationship between career management and management failure at SMEs levels. Among others, it was suggested that vocational education should be given proper attention so as to prepare people for entrepreneurship ventures which hold the key to economic development in this century and beyond.
\end{abstract}

Funding: This study receive no specific financial support.

Competing Interests: The author declares that there are no conflicts of interests regarding the publication of this paper.

Acknowledgement: I acknowledge Prof. C. M Odozi whose lecture notes on Strategic Human Resource Management helped in this work.

\section{Introduction}

People in their various spheres of life directly or indirectly examine, manipulate or exploit their immediate environments, the consequences of which are later translated to either challenges or prospects of their organizations. The human element is therefore, the most important and versatile resource in any organization. It is the recognition of people as being central to achieving organizational objectives that has made successful organizations to develop career management mechanisms to equip employees to perform at optimal levels. Good career management thrives on sound education that provides the basis for positive behaviour and performance. At the most general level, education is recognized as a process of shaping behaviour of the individual for adequate adjustment in the society. A most fundamental function of education is to sharpen the individual properly by drawing out and developing whatever that is distinctively human in him to enable him contribute positively to the development of humanity and society. Based on these lines of thought, organizations develop career imperatives to enhance employee performance. A career is defined as "the individually perceived sequence of attitudes and behaviours associated with work-related experiences and activities over the span of the person's life". According to Odozi (2003) interest in the concept of careers and career development in organizations has existed for many years. This interest emphasizes the institutionalization of organizational patterns, offer them a variety of development options, and forming the link between current performance and future development, which includes the notion of best fit or match; that gives rise to enhancing employee performance through career management processes. It is also understood that management is a critical link in the career management process of their employees. The organization or the management is responsible for providing tools and support for employee self-development, training and development, education, and for reinforcing management's role in career management. Employee performance 
which is a reflection of his or her output in terms of organizational profitability or productivity is fundamentally a function of employee development; which is also directly linked with career management. Employee development involves a combination of formal education, job experiences, relationships, and assessment of personality, and abilities to help employees prepare for the future so as to take up higher responsibilities in their careers (Noe, Hollenbeck, Gerhart, \& Wright, 2004). Career management through corporate education is imperative to the survival of any organization due to the rapid changes in the global economy where business is knowledge-driven. Consequently, organizations must continually strive to upgrade the knowledge base and skill levels of their work-force in order to keep up with the ever-changing demands of the global marketplace and advances in technology. According to Kaliski (2001) a corporation's future is determined largely by its involvement in the development of its intellectual resources. Today organizations are expanding the education segment of their business activity, realizing quickly that without this input, they will easily lose their competitive edge in a highly growing and competitive global economy. He postulates that not only is continuing education vital to the future success of any organization, it is of equal importance that employees remain adaptable and agile learners in order to benefit personally and professionally from available opportunities. Therefore, investing in the right programme, for the right people, at the right time will continue to be a challenge for organizations as they strategically attempt to capitalize on the vast economic opportunities available to them in this twenty-first century and beyond. Some of the methods for career management for the enhancement of employee performance in terms of corporate education, include, but not limited to education, training and development, independent study, among others. Armstrong (2004) emphasize that another important reason for corporate education is that many highly successful businesses are abandoning the multilayered hierarchical organizational patterns in pursuit of a structure that empowers managers with the authority to solve problems and make decisions in areas that affect their areas of expertise. Also, corporate restructuring, as well as high-speed technological advances provide employees broader responsibilities that require more skills and training for self-managed, cross-functional teams. Therefore, career management has become the catalyst for employee performance and enterprise profitability. Armstrong (2004) states the overall aim of career management to include; ensuring that the organizations' needs for management succession are satisfied, to provide men and women of promise with sequence of training to equip them for whatever level of responsibility, and to give individuals with potential the guidance and encouragement they need to achieve a successful career with the organization in tune with their talents and aspirations (Ugoani, 2015; Ugoanii \& Nwaubani, 2014).

\subsection{Research Problem}

A major problem for career management is weak foundational education in some countries, despite the fact that education is the primary agent of change in society. For example, it is estimated that Nigeria has over 10.5 million out-of-school children, out of which about 60 percent of this figure represents the girl-child; this problem can make it difficult for employers to access quality employees for organizational performance (Adeyemi, 2019). Also, a critical challenge for organizations to survive in the competitive business world is how to raise employees with the required competencies for high performance. Often organizations become complacent in the hope that they have an abundance of educated employees who are sufficiently familiar with existing ICTs. However, as witnessed during the preceding century, continuous technological development and changes through the Internet superhighway have changed the mode of doing business that calls for continuous employee education, training and development, assessment, mentoring, appraisal, among other techniques to raise their performance. The challenge is high in terms of cost and innovation but it remains a task that must be done because marketing, customer services, and many other areas of business and the economy, and changing corporate culture demand increasing levels of employee competence. This becomes imperative because lack of training, whether through traditional classes, continuing education venues, or informal work groups places organizations at a distinct disadvantage in international commerce. Kaliski (2001) explains that the most important goal of any corporation is to increase profits. Consequently, without an ongoing commitment to work-force education, businesses set themselves up for failure. He insists that complacency over employee education ensures that organizational goals will never be attained.

\subsection{Research Objective}

This study was designed to investigate the relationship between career management and employee performance.

\subsection{Research Significance}

This work is significant today that the world is in the race for sustainable development. It will help to refocus the attention of business organizations, charitable organizations, governments and others toward the need for improved corporate education as a major instrument for driving sustainable development. This is not an overstatement because education is power, and information through education, training and development is super power. In any organization the positive effect of education has a trickle-down effect throughout the organization. Through it employees have the information they need to make better decisions, better decisions 
lead to better performance. Lattimore, Baskin, Heiman, Toth, and Van Leuven (2004) posit that informed people out-perform uniformed people, when all else is equal.

\subsection{Research Questions}

1. Does corporate education enhance employee performance?

2. Can you use assessment to improve employee performance in organizations?

3. Is training a factor in career management?

4. Is mentoring necessary career management tool?

5. Can appraisal help to increase employee performance?

\subsection{Hypothesis}

To achieve the objective of this study this hypothesis was formulated and tested at 0.05 level of significance.

Ho: There is no relationship between career management (CM) and employee performance (EP).

$H i$ : There is a relationship between career management $(C M)$ and employee performance $(E P)$.

\subsection{Conceptual Framework}

A conceptual framework is a structure of the study showing its hypothesized relationship with the variables of the study in relation to the study problem. It is usually demonstrated in a diagrammatic form as a model. Models are increasingly used as important research tools and necessary to explain important issues that would otherwise be buried in an excess of words. Conceptual models are also important in theory building (Keeves, 1997; Meredith, 1993). The model for this study is shown in Figure 1.

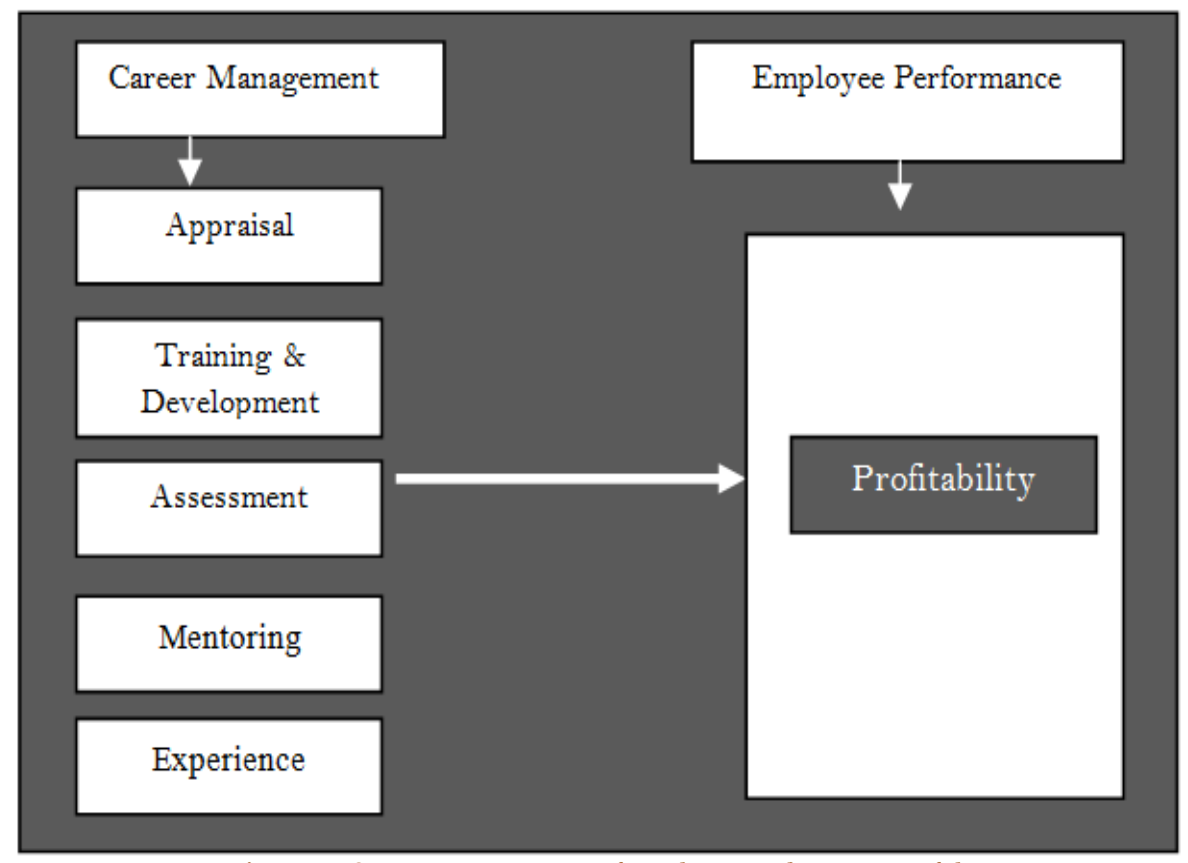

Figure-1. Career management and employee performance model.

Career management involves performance appraisal which relates to the measurement of specified areas of an employee's performance. It helps to determine employee's eligibility for higher responsibilities or areas that require significant improvement. Training and development help the employee to acquire new skills after a certain level of formal education to enable him perform specific duties and prepare for higher responsibilities within the organization.

Assessment, like benchmarking involves collecting information on employee performance and providing feedback to enable the employee improves upon performance where necessary. Also, mentoring, learning and experience provide important ways to bring up new employees and place them in a better stead for better performance. These are among the important corporate education components that equip employees for better performance and improved enterprise profitability (Kaliski, 2001; Owolabi \& Makinde, 2012; Shih, Chiang, \& Hsu, 2006).

\section{Literature Review}

Armstrong (2004) explains that career management consists of the processes of career planning and management succession. Career planning therefore shapes the progression of employees within an 
organization in accordance with assessments of organizational needs and the performance, potential and preferences of the employees of the enterprise. At the same time, management succession planning takes place to ensure that as far as possible, the organization has the managers it requires to meet future business needs. Accordingly, career planning can be regarded as forming part of a career system which is the set of policies and practices an organization uses to provide for its human resource requirements. Organizational goals can best be achieved through the skills of the employees made possible through motivation, job satisfaction and organizational citizenship behavior (Hardré, 2003; Hewitt, 2009; Koch \& McGrath, 1996; Nwuche \& Awa, 2011). Career management emphasizes continuous education and learning. Learning is the process of increasing employee's capacity to take action.

Learning should be distinguished from training, because, it is the process by which a person acquires new knowledge, skills and capabilities whereas training is one of several responses, an organization can take to promote learning. A distinction is also made between learning and development by (Pedler, Boydell, \& Burgoyne, 1989) that learning is concerned with an increase in knowledge or a higher degree of an existing skill, while development is more toward a different state of being or functioning. Argyris (1992) points out that learning are not simply having a new insight or a new idea. Rather, learning occurs when people take effective action, detect and correct error. It is a systematic procedure for acquiring necessary skills, advancing knowledge, causing behavioural change needed by current workers in order to achieve desired result. Also, development consists of activities that increase the competence and ability of employees to progress within the organization as it progresses and grows.

Agbato (1990) posits that employee training is necessary to get jobs done now, and employee development is necessary if the potential of the current workforce is to be realized later, while education coupled with experience is required to prepare people to move ahead in the organization. He therefore, describes training as the act of equipping employees with the necessary methods and techniques to enable them perform competently in their present or future jobs so as to increase efficiency and output of the organization as well as obtaining self-satisfaction. To this extent, training is a systematic intentional process of altering the behaviour of organizational members in a direction which contributes to employee performance and organizational effectiveness. Even though organizational effectiveness may be defined as the extent to which multiple goals are achieved, it is however, more than profitability and includes other factors like employee satisfaction, goal integration and group functioning (Argyriss \& Schon, 1996; Gandhi \& Sachdeva, 2018).

\subsection{The Organization and Career Management}

Many organizations today are looking at career management as a response to key organizational issues. Successful organizations implement career management programmes to help in reducing the traditionally high turnover rates, and placing emphasis on on-the-job, development and its important role in learning and career development (Torraco \& Swanson, 2015; Ugoani, 2018; Ugoanie, 2016). Career development systems must be integrated with other human resource management strategies with the overall aim of achieving an improved performance with management and employees having positive fulfilment. The effectiveness of a career development system lies in its consideration of the interaction, interdependence, and integration of all the elements within an organization. The best approach toward a fine career development system is to ensure that it has a clearly defined responsibility for the employees, the managers and the management team (Solkhe \& Chaudhary, 2011; Turnipseed \& Rassuli, 2005). According to Noe et al. (2004) the concept of a career has changed in recent years. In the traditional view, a career consists of a sequence of positions within an occupation or organization.

For example, an academic career might begin with a position as an adjunct professor in a university and continues to assistant professor, then associate professor, and finally full professor. In this example, the career resembles a set of stairs from the bottom of a profession to the top. But now the new concept of a career is often referred to as a protean career, meaning a career that frequently changes based on changes in the individual's interests, abilities, and values and in the work environment. The concept of protean career assumes that employees will take major responsibility for managing their careers. This means that this concept is consistent with the modern psychological contract. In place of the traditional expectation of job security and advancement within an organization, and in tandem with the modern psychological contract, employees of today need to take control over their careers and personal responsibility for managing their careers. They look for organizations that will support them by providing development opportunities (D. E. Guest \& Conway, 1997; D. E. Guest \& Conway, 1998; D. E. Guest, Conway, Briner, \& Dickman, 1996; Guestt \& Conway, 2002). On these important issues of training and development, and career management, Noe et al. (2004) insist that organizations and their employees must constantly expand their knowledge, skills, and behaviour to meet customer needs and compete in the current demanding and rapidly changing business environment. They posit that modern organizations are expected to provide development opportunities to employees without regard to their sex, race, ethnic background, or age, so that they have equal opportunity for advancement. In this regard, successful organizations are placing greater emphasis on education, training and development. To 
achieve the desired objectives, organizations must understand the relationship in regard to training and development and career management (Smith, 1986).

\subsection{Career Management Process}

According to Odozi (2003) a career management process provides an interface between current performance and future development. Employees and managers must therefore consider factors related to improving and maintaining their performance in current job function and future options, while striving for a best fit, or best match, between their skills and the organization's requirement. Noe et al. (2004) suggests that employee development is most likely to meet the organization's needs if it is part of a human resource system of career management. According to them, in practice, organizations' career management systems vary. Some rely heavily on formal relationships, while others have sophisticated arrangements. Broadly speaking, however, a basic career management system involves four steps: self-assessment, reality check, goal setting and action planning.

At each step, both the employee and the organization have responsibilities. These researchers emphasize that the system is most likely to be beneficial if it is linked to the organization's objectives and needs, has support from top management, and is created with employee participation (McCracken, 2000; Rothwell, 2001; Snell, 1990). Management has huge responsibility to implement robust career management system for the benefit of employees and the organization. From career management policies, and through demand/supply forecasts, performance and potential assessment, succession planning, recruitment, induction, mentoring and management training, among others, there will be clear beneficial career progression. For example, mentoring as an approach in the career management process helps to accelerate the experience curve of employees. Mentoring is a process of using specially selected and trained individuals to provide guidance and advice which will help to develop the careers of the protégés allocated to them. Mentoring is aimed at complementing learning on the job, which must always be the best way of acquiring the particular skills and knowledge the job holder needs.

Mentoring also complements formal training by providing those who benefit from it with individual guidance from experienced managers who are wise in the ways of the organizations (Ragins, Cotton, \& Miller, 2000; Seibert, 1999; Wilson \& Elman, 1990). Management development or training which often forms the last part of corporate education is concerned with improving managers' performance in their present roles and preparing them for greater responsibilities in the future. Mumford (1994) posits that management development must be business led, even though it is concerned with the development of individual performance and potential. He explains that the organization has to decide what sort of managers it needs to achieve its strategic goals and the organization must decide how it can best obtain and develop these managers (Van Wart, Cayer, \& Cooks, 1993).

Management training emphasizes management strategy and mechanisms for management control, communications, co-ordination, and monitoring, learning and adjustment. It is expected that for these processes to be effective, organizational structures must become less hierarchical and more open to information and to employee initiative at all levels. There is also need to focus on adaptive strategies that require very flexible management processes. Often, incremental planning, decentralization of decision-making and participatory forms of authority and leadership are central to flexibility. According to Middleton, Ziderman, and Adams (1993) organic structures focus more on performance and much less on conformance to rules and standard operating procedures. They posit that to function effectively within adaptive management structures employees need a high level of professionalism and the ability to work effectively under ambiguous and uncertain circumstances. They further explain that mechanistic and adaptive management strategies define opposite ends of a continuum of approaches, and in practice most organizations use elements of both, depending on the tasks to be accomplished. On the whole it is almost always true that education, training and development and learning role enhances employee performance, customer satisfaction, and also ensures that the organization achieves its objectives efficiently (Ahmad \& Schroeder, 2013; Boselie, Dietz, \& Boon, 2015; Gagne, 1995; Gerhart \& Trevor, 2016; David E Guest, 1997; Lee \& Bruvold, 2013; Swanson, 2015).

\section{Research Methodology}

Research is the process of arriving at dependable solutions to problems through planned and systematic collection, analysis, and interpretation of data.

\subsection{Research Design}

The exploratory research design was used for the study. A combination of quantitative and qualitative techniques can be used in exploratory research (Cresswell, 2009). This method is historical in nature and does not often require a large sample or a structured questionnaire. The strength of qualitative research technique lies in its capacity to provide proper insights, rich details and thick descriptions. Richness is provided by paying close attention to concept, context and process (Abebrese \& Smith, 2014). 


\subsection{Sources of Data}

Data were generated from secondary and primary sources such as: books, journal articles, annual reports, government reports, personal interviews, observations, among others. Secondary data are information collected previously for some other purpose other than the research project at hand whereas primary data are information gathered and assembled especially for the research objective at hand (Aakar, Day, \& Kumar, 2004). Each data collection method has advantages, and disadvantages. However, according to Nelson and Quick (2003) the best approach is using multiple method of collecting data because it offers the researcher a chance to cross-check the information obtained through the various methods.

\subsection{Population, Sample and Size}

The population comprised of all the financial institutions (FIs) in Nigeria. The sample was selected through the purposive method, while the size was determined using the sample ratio concept (Obodoeze, 1996).

\subsection{Study Area}

This study was conducted in South-East Nigeria composed of five states out of thirty six states in Nigeria. It is believed that the opinion of the people in this area is representative of the opinion of the people in Nigeria based on the $1 / 10^{\text {th }}$ principle (Ezejelue, Ogwo, \& Nkemnabe, 2008).

\subsection{Model Specification}

Model specification is the expression of a relationship into precise mathematical form. According to Koutsoyannis (1977) economic theory does not indicate the functional form of any relationship. This means that economic theory does not state whether a relationship will be expressed in linear form, quadratic form, or in a cubic form. on the basis of these it was chosen to specify the relationship between employee performance $(\mathrm{EP})$ and career Management $(\mathrm{CM})$ as:

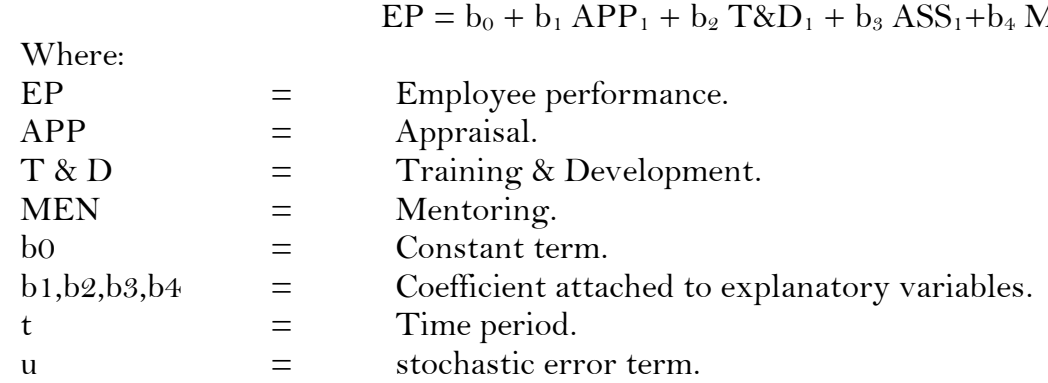

\subsection{Data Analysis}

Data were analyzed through descriptive and regression statistical methods. The Ordinary Least Square (OLS) technique is a method used to estimate the unknown parameter in a linear regression model with the goal of minimizing the differences between observed variances in a dataset. The method was not chosen because of its simplicity, but also due to its unique properties of linearity, efficiency, sufficiency, least variances, unbiasedness, and least mean errors. The F-test and t-test were used to determine the overall adequacy of the regression model using the E-View Statistical Package (Edmondson \& McManus, 2007; Nwankwo, 2011).

\section{Presentation of Result}

Table-1. Profile of respondents $(\mathrm{n}=80)$.

\begin{tabular}{c|c|l|c|c}
\hline S/N & Description & Category & Total & Percentage \\
\hline 1 & Sex & a) Female & 45 & 56.25 \\
& & b) Male & 35 & 43.75 \\
\hline 2 & \multirow{2}{*}{ Education } & a) Diplomas & 20 & 25.00 \\
& & b) Degrees & 50 & 62.50 \\
& & c) Others & 10 & 12.50 \\
\hline 3 & \multirow{2}{*}{ Age } & a) $18-30$ years & 30 & 37.50 \\
& & b) $31-75$ years & 50 & 62.50 \\
\hline 4 & \multirow{2}{*}{ Experience } & a) $5-10$ years & 15 & 18.75 \\
& & b) $11-20$ years & 30 & 37.50 \\
& & c) $21-35$ years & 35 & 43.75 \\
\hline 5 & \multirow{2}{*}{ Status } & a) Low & 18 & 22.50 \\
& & b) Middle & 40 & 50.00 \\
& & c) High & 22 & 27.50 \\
\hline
\end{tabular}


Table 1 was used to analyze the characteristics of the respondents.

Table-2. Frequency and mean for response to research question.

\begin{tabular}{|c|c|c|c|c|c|c|c|c|c|c|}
\hline \multirow{3}{*}{$\mathbf{S} / \mathbf{N}$} & \multirow{3}{*}{$\begin{array}{l}\text { Restatement of research } \\
\text { questions }\end{array}$} & \multicolumn{5}{|c|}{ Scores } & \multirow[b]{3}{*}{$\boldsymbol{\Sigma}_{\mathbf{X}}$} & \multirow[b]{3}{*}{$\bar{n}$} & \multirow[b]{3}{*}{$\overline{\mathbf{X}}$} & \multirow{3}{*}{$\begin{array}{c}\text { Decision } \\
\text { rule@3 } \\
\text { points }\end{array}$} \\
\hline & & $\mathbf{S A}$ & A & $\mathbf{N}$ & $\mathbf{D}$ & SD & & & & \\
\hline & & 5 & 4 & 3 & 2 & 1 & & & & \\
\hline 1 & $\begin{array}{l}\text { Corporate education enhances } \\
\text { employee performance }\end{array}$ & 40 & 20 & 1 & 4 & 15 & 306 & 80 & 3.83 & Accepted \\
\hline 2 & $\begin{array}{l}\text { Assessment cannot be used to } \\
\text { improve employee performance } \\
\text { in organizations }\end{array}$ & 10 & 15 & 2 & 10 & 43 & 179 & 80 & 2.24 & Rejected \\
\hline 3 & $\begin{array}{l}\text { Training is an important factors } \\
\text { in career management }\end{array}$ & 45 & 10 & 3 & 5 & 17 & 301 & 80 & 3.76 & Accepted \\
\hline 4 & $\begin{array}{l}\text { Mentoring is necessary in career } \\
\text { management }\end{array}$ & 42 & 25 & 2 & 2 & 9 & 329 & 80 & 4.11 & Accepted \\
\hline 5 & $\begin{array}{l}\text { Appraisal does not help to raise } \\
\text { employee performance }\end{array}$ & 15 & 10 & 3 & 2 & 50 & 178 & 80 & 2.23 & Rejected \\
\hline
\end{tabular}

Source: Fieldwork (2019).

Table 2 showed the responses to the research questions (Nwankwo, 2011).

\begin{tabular}{c|c|clc}
\multicolumn{5}{c}{ Table-3. Regression analysis. } \\
\hline Variables & Coefficient & Std. error & t-statistic & Prob. \\
\hline C & 3.651274 & 0.045957 & 79.44959 & 0.0000 \\
APP & 0.319014 & 0.059678 & -5.345626 & 0.0000 \\
T\&D & 0.008350 & 0.001016 & 8.217525 & 0.0000 \\
ASS & -0.014203 & 0.004764 & -2.981343 & 0.0037 \\
MEN & 0.080833 & 0.007400 & 10.82388 & 0.0000 \\
\hline R-squared & 0.940149 & Mean dependent var & 4.002356 \\
Adj. R-squared & 0.930291 & S.D. dependent var & 0.580986 \\
S.E. of regression & 0.153395 & Akaike info criterion & 0.774121 \\
Sum squared resid & 2.000056 & Schwarz criterion & -0.383346 \\
Log likelihood & 53.70606 & Han-Quinn criterion & -0.615967 \\
F-statistic & 95.37015 & Durbin-Watson stat & 1.803222 \\
Prob (F-statistic) & 0.000000 & & \\
\hline
\end{tabular}

Table 3 was used to establish the relationship between CM and EP.

\subsection{Discussion}

Since human resource is accepted as the most important element of production career management becomes crucial to ensure that employees have the requisite capacity to contribute to enterprise performance. Eighty knowledgeable respondents participated in the study so as to help in triangulating the information from secondary and primary sources. 56.25 percent of the respondents were male, while 43.75 percent were female, with different levels of education. 37.50 percent were in the age range between 18.30 years, while the rest 62.50 percent were between 31 and 75 years, and also in different levels of economic status, as shown in Table 1. Table 2 described the responses of the participants to the research questions. For example, in Table 2 (1) the respondents agreed at 3.83 points that corporate education enhances employee performance. This supports the views of Kaliski (2001) that corporate education empowers employees to take on broader responsibilities that require more skills and training for self-managed, cross-functional teams. As in Table 2 (2) the respondents rejected at 2.24 points that assessment is not necessary to improve employee performance in organizations, to agree with Noe et al. (2004) that assessment is a necessary tool for employee performance improvement. It was accepted at 3.76 points that training and development role enhances employees performance. This position lends credence to the findings of Agbato (1990) that training and development process is the catalyst for employee performance and organizational effectiveness. He posits that it is through this process that the necessary technical ability required to enhance efficiency and increased productivity is developed. The analysis also provided evidence that mentoring and appraisal are critical measures in career management and employee performance. According to Armstrong (2004) mentoring helps newcomers to gain experience from older employees who are seen as role models and this is an important HRM tool for improved employee performance. The analysis in Table 3 proved that career management has positive correlation with employee performance. In regression analysis, there is an important measure, $\mathrm{R}^{2}$, which measures the goodness-of-fit of the regression model. By this, it calculates the percentage of variation in the dependent variable accounted for by the independent variable(s). The possible values of $\mathrm{R}^{2}$ range from 0 to 1.00 . The 
closer $\mathrm{R}^{2}$ is to 1.00 the greater the percentage of the explained variation. A high value of $\mathrm{R}^{2}$ of about .80 or more would indicate that the independent variable is a good predictor of values of the dependent variable of interest. A low value of about .25 or less would indicate a poor predictor, and a value between .25 and .80 would suggest a moderate predictor (Gujarati, 2003). In this study, the $\mathrm{R}^{2}$ value of .94 showed a strong positive relationship between the variables of interest. The goodness-of-fit test of the model is also excellent in view of the adjusted $\mathrm{R}^{2}$ value of .93 . The value of Durbin-Watson is 1.8 that lies within the range between 1.5 and 2.5. Therefore, in this study, it can categorically be stated that there is no autocorrelation among the independent variables of interest. The F-test and t-test were also significant at 0.05 levels. In view of this therefore, Ho: was rejected and Hi: accepted to affirm that career management has strong positive relationship with employee performance. This is the objective of the study.

\subsection{Recommendations}

1. Organizations should pay more attention to corporate education to improve the efficiency of their employees.

2. Government needs to introduce a legislation to strengthen national training and development agencies to enable them enforce corporate education at institutional levels to improve economic progress.

3. Employees should be encouraged over self-development as a method of improving their performance on the job.

4. Privately-held organizations should cultivate the culture of training and developing their employee as a major contribution to national development.

5. Vocational education should be given proper attention to prepare people for entrepreneurship ventures which hold the key for economic development in this century and beyond.

\subsection{Scope for Further Study}

Further study should examine the relationship between career management and management failure at small and medium enterprises, (SMEs) level. In many developing countries like Nigeria, most SMEs collapse after 1 or 2 years after the demise of the original founder due to lack of succession planning.

\subsection{Research Limitations}

The study was constrained by lack of research grant and relevant current literature. However, these limitations never diluted the academic potency of this original investigation.

\section{Conclusion}

Career management provides the basis for employees to acquire the necessary skills they require to perform at optimal levels. This can be achieved through mentoring and experience, training and development, assessment and or appraisal mechanisms. Training and development role helps to prepare employees to perform optimally in their present job and also helps to prepare them for broader responsibilities in the future. Corporate education generally, helps employees and managers to adapt to changing environments that require very flexible management approaches, it give them the opportunity to learn how to function effectively within adaptive management structures and the ability to work under ambiguous and uncertain circumstances. Eighty respondents participated in this study conducted through the exploratory research design. Analysis through descriptive and regression statistical techniques showed a strong positive relationship between career management and employee performance.

\section{References}

Aakar, D. A., Day, G. S., \& Kumar, V. (2004). Marketing research (8th ed.). Hoboken, N: John Wiley.

Abebrese, A., \& Smith, R. (2014). Developing a phenomenological understanding of the influence of 'Cultural survival mechanisms' as institutional artifacts in shaping indigenous Enterprise Cultures: A Ghanaian Perspective. Amity Business Journal, 3(1), 11-21.

Adeyemi, K. (2019). Osinbajo hails Ganduje for launching education revolution in North. The Nation, 13(4783), 42.

Agbato, J. O. (1990). The nature of management: A text for professionals (Revised Edition). Lagos: Abiola Bookshop Press Limited

Ahmad, S., \& Schroeder, R. G. (2013). The impact of human resource management practices on operational performance: recognizing country and industry differences. Journal of Operations Management, 21(1), 19-43.

Argyris, C. (1992). On organizational learning. Cambridge: Blackwell Mass.

Argyriss, C., \& Schon, D. A. (1996). Organizational learning. A theory of action perspective. Addison-Wesley: Reading, Mass.

Armstrong, M. (2004). A handbook of human resource management practice (9th ed.). India: Kogan Page.

Boselie, P., Dietz, G., \& Boon, C. (2015). Commonalities and contradictions in HRM and Performance Research. Human Resource Management Journal, 15, 67 - 94.

Cresswell, J. (2009). Research design: Qualitative, quantitative and mixed method, approaches. London: Sage Publication.

Edmondson, A. C., \& McManus, S. E. (2007). Methodological fit in management field research. Academy of Management Review, 32(4), 1246-1264. Available at: https://doi.org/10.5465/amr.2007.26586086. 
Ezejelue, A., Ogwo, E. O., \& Nkemnabe, A. (2008). Basic principles in managing research projects (2nd ed.). Port Harcourt: Education Books Ltd.

Gagne, R. M. (1995). Learning processes and institutions. Training Research Journal, 1, 17-28.

Gandhi, M., \& Sachdeva, T. (2018). Impact of diverse values of employees on organizational effectiveness. Amity Business Journal, $7(11), 11-17$.

Gerhart, B., \& Trevor, C. O. (2016). Employment variability under different managerial compensation systems. Academy of Management Journal, 39, 1692 - 1712.

Guest, D. E. (1997). Human resource management and performance: A review and research agenda. International Journal of Human Resource Management, 8(3), 263-276.

Guest, D. E., \& Conway, N. (1997). Employee motivation and the psychological contract. London: Institute of Personnel Development.

Guest, D. E., \& Conway, N. (1998). Fairness at work and the psychological contract. London: Institute of Personnel Development.

Guest, D. E., Conway, N., Briner, R., \& Dickman, M. (1996). The state of the psychological contact in employment: Issues in people management. Institute of Personnel Development: London.

Guestt, D. E., \& Conway, N. (2002). Communicating the psychological contract: An employer perspective. Human Resource Management Journal, 12(2), 22-38.

Gujarati, D. N. (2003). Basic econometrics (4th ed.). New York: McGraw-Hill.

Hardré, P. L. (2003). Beyond two decades of motivation: A review of the research and practice in instructional design and human performance technology. Human Resource Development Review, 2(1), 54-81. Available at: https://doi.org/10.1177/1534484303251661.

Hewitt, A. (2009). Managing performance with incentive pay. Journal of Personnel Management, 7(1), $20-31$.

Kaliski, B. S. (2001). Corporate education. In B. S. Kaliski (Ed). Encyclopedia of business and finance (Vol. 1, pp. 191 - 195). USA: Macmillan Reference.

Keeves, J. P. (1997). Models and model building. In J. P. Keeves (Ed.), Educational research methodology and measurement: An International Handbook (2nd ed.). Cambridge UK: Pergamon.

Koch, M. J., \& McGrath, R. G. (1996). Improving labor productivity: Human resource management policies do matter. Strategic Management Journal, 17(5), 335-354. Available at: https://doi.org/10.1002/(sici)10970266(199605) 17:5<335::aid-smj814>3.3.co;2-i.

Koutsoyannis, A. (1977). Theory of econometrics. Humpshire: Macmillan and Evans Ltd.

Lattimore, D., Baskin, O., Heiman, S. T., Toth, E. L., \& Van Leuven, J. K. (2004). Public relations: The profession and the practice (pp. $346-369)$. Boston: McGraw-Hill.

Lee, C. H., \& Bruvold, N. T. (2013). Creating value for employees: Investment in employee development. The International Journal of Human Resource Management, 14, 981 - 1000.

McCracken, D. M. (2000). Winning the talent war for women: Sometimes it takes a revolution. Harvard Business Revierw, $78(6), 159-167$.

Meredith, J. (1993). Theory building through conceptual methods. International Journal of Operations \& Production Management, 13(5), 3-11. Available at: https://doi.org/10.1108/01443579310028120.

Middleton, J., Ziderman, A., \& Adams, A. A. (1993). Skills for productivity: Vocational education and training in developing countries (pp. 253-277). New York: Oxford University Press.

Mumford, A. (1994). Management Development: Strategies for action. London: Institute of Personnel Management.

Nelson, D. L., \& Quick, J. C. (2003). Purposes of scientific research: Applied and basic research. In D. L. Nelson and J. C. Quick (Eds.), Organizational behaviour: Foundations, Realities and Challenges (4th ed., pp. 656 - 671). USA. South-Western.

Noe, R. A., Hollenbeck, J. R., Gerhart, B., \& Wright, P. M. (2004). Fundamentals of human resource management. Boston: McGraw-Hill, Irwin.

Nwankwo, O. C. (2011). A practical guide to research writing for students research enterprise (Revised Fourth Edition). Port Harcourt: Pam Unique Publishers.

Nwuche, C., \& Awa, H. (2011). Career planning and development: The realities in Nigerian organizations. International Business \& Management, 2(2), 117-127.

Obodoeze, F. O. (1996). Modern textbook of research methodology. Enugu: Academic Publishing Company.

Odozi, C. M. (2003). Strategic human resource management. Unpublished MSc, Lecture Notes. ESUT Business School, Enugu, Nigeria.

Owolabi, S. A., \& Makinde, O. G. (2012). The effects of strategic planning on corporate performance in university education: A study of Babcock University. Kuwait Chapter of Arabian Journal of Business and Management Review, 33(853), 1-18.

Pedler, M., Boydell, T. m., \& Burgoyne, J. (1989). Towards the learning company. Management Education and Development, 2O(1), $1-8$.

Ragins, B. R., Cotton, J. L., \& Miller, J. S. (2000). Marginal mentoring: The effects of type of mentor, quality of relationship, and program design on work and career attitudes. Academy of Management Journal, 43(6), 1177-1 194. Available at: https://doi.org/10.5465/1556344.

Rothwell, W. J. (2001). Effective succession planning (2nd ed.). New York: AMACOM.

Seibert, S. (1999). The effectiveness of facilitated mentoring: A longitudinal quasi-experiment. Journal of Vocational Behavior, 54(3), 483-502. Available at: https://doi.org/10.1006/jvbe.1998.1676.

Shih, H.-A., Chiang, Y.-H., \& Hsu, C.-C. (2006). Can high performance work systems really lead to better performance? International Journal of Manpower, 27(8), 741-763.

Smith, D. (1986). Training programs for performance appraisal: A review. Academy of Management Review, 11(1), 22-40. Available at: https://doi.org/10.2307/258329. 
Snell, R. (1990). Congenial ways of learning: So near and yet so far. Journal of Management Development, 9(1), 17-23.

Solkhe, A., \& Chaudhary, N. (2011). HRD climate and job satisfaction: An empirical investigation. International Journal of Computing and Business Research, 2(2), 1-20.

Swanson, R. A. (2015). Human resource development: Performance is the key. Human Resource Development Quarterly, 6, 207 $-213$.

Torraco, R. J., \& Swanson, R. A. (2015). The strategic roles of Human resource development. People and Strategy, 18, 10.

Turnipseed, D. L., \& Rassuli, A. (2005). Performance perceptions of organizational citizenship behaviours at work: A bilevel study among managers and employees. British Journal of Management, 16(3), 231-244.

Ugoani, J. N. N. (2015). Emotional intelligence and transformation of management education for organizational profitability. Independent Journal of Management \& Production, 6(4), 1047 - 1069.

Ugoani, J. N. N. (2018). The role of training and development in performance effectiveness in Nigeria. American Journal of Business and Society 3(1), $17-27$.

Ugoanie, J. N. N. (2016). Employee turnover and productivity among small business entities in Nigeria. Independent Journal of Management \& Production, Brazil, 7(4), 1063 - 1082. Available at: https://doi.org/10.14807/ijmp.v7i4.466.

Ugoanii, J., \& Nwaubani, A. (2014). Entrepreneurship education as helicopter for entrepreneurship development: Nigerian perspective. International Journal of Management Sciences, 4(4), 182-198.

Van Wart, M., Cayer, N. J., \& Cooks, S. (1993). Handbook of training and development for the public sector. Jossey-Bass: San Francisco.

Wilson, A., \& Elman, N. S. (1990). Organizational benefits of mentoring. Academy of Management Executive, 4, $88-93$. 